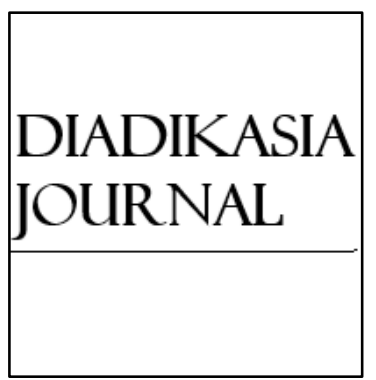

Diadikasia Journal

ISSN: $2721-9070$

Copyright $\odot 2020$ Diadikasia Organization

https://diadikasia.pubpub.org/

Volume 1(1): 103-114

DOI: $10.21428 / 8$ c841009.a6eedoc3

\title{
POWER (PLAN, ORGANIZE, WRITE, EDIT, AND REVISE) STRATEGY: TEACHING WRITING VIEWED FROM STUDENTS' CREATIVITY
}

\author{
Tia Nur Istianah \\ tianur.07@gmail.com \\ UPT PBB IAIN Syekh Nurjati \\ Jl. Perjuangan, Cirebon, Indonesia 45131
}

\begin{abstract}
POWER (Plan, Organize, Write, Edit, and Revise) is an organizational strategy to produce good writing by exploring and reinforcing students' ideas through the stages of the writing process. This article considers an experimental study on the effectiveness of POWER strategy to teach writing viewed from students' creativity at one Senior High School in Surakarta. The sampling used in this research was clustering sampling with two classes as samples, namely experimental class taught using POWER strategy, and control class taught using guided writing. In this research, there were two instruments to collect the data: writing and verbal creativity tests. The data obtained were analyzed by using $2 \times 2$ Multifactor Analysis of Variance (ANOVA) and Tukey test. The result of the research shows that: (1) POWER strategy is more effective than guided writing to teach writing; (2) students having high creativity have better writing than those having low creativity; and (3) there is an interaction between teaching strategies and creativity. It means that the use of the POWER strategy is useful to teach writing.
\end{abstract}

Keywords: POWER strategy, Guided writing, Writing skill, Creativity.

\section{Introduction}

English is beyond doubt the most significant language in the world. The existence of the English language as one of the communication tools is to break down language barriers among people with different races, cultures, and nationalities. Learning English can support many fields, for example, education. In Indonesia, English also becomes a necessity for students. They taught four skills of English, namely listening, speaking, reading, and writing. Among those skills, writing is a productive skill that is important because writing is a means of communication. Huy (2015) states that writing is the most 
crucial skill in English because it is not only an academic skill but also an essential skill that can use in any career fields such as business, science, and technology.

However, many students still are not aware of the importance of writing, and most students get difficulty in learning writing. This problem appears because writing as one of the four skills that have crucial functions and is considered the most difficult. Barkaoui (2007) argues that writing is the most challenging skill that second language (L2) learners expected to acquire, requiring the mastery of a variety of linguistic, cognitive, and sociocultural competencies. In line with Bakaoui's statement, Kellogg (2008) also states that learning how to write a coherent and effective text is ambiguous. This problem appears because many students have a limited vocabulary, knowledge of grammar, topic, and exercise to express their ideas into writing.

Due to the case, the students need to have an excellent ability to produce good sentences and paragraphs using effective teaching strategies. As a facilitator and controller in the classroom, the teacher should be more creative in providing and applying appropriate and exciting strategies to teach writing skills. For instance, the use of the POWER strategy to teach writing can help the students to produce good writing. Fazio and Gallagher (2009), POWER is a memory mnemonic used as a strategy to reinforce the steps of the writing process, and it suitably used for a writing activity.

Kamilasari (2013) argues that POWER strategy is a strategy which helps students to organize and explore their ideas quickly as soon as it comes to their mind. In its implementation, the students asked to collect ideas about the topic and organize ideas for each paragraph. In the writing stage, the students have to develop the ideas into a paragraph systematically. In the last stage, this strategy gives students a chance to check and revise their writing based on the result of the correction. The POWER strategy, the students are expected to be independent and make a success when writing by encouraging them to use an organized and systematic way.

Producing written works is also more complicated. Students demanded to have not only language skills but also other factors, namely creativity. Creativity is assumed to be an essential human characteristic which influences students' writing skill. Theoretically, creativity involves imagination, originality, productivity, problem-solving, and the ability to produce an outcome of value and worth. Craft (2001) argues that creativity is a state of mind. She believes that creativity requires the capacity to live with complexity and uncertainty. Concerning the importance of creativity in writing, it believes that creative writing can develop students' language proficiency, and engage students in writing more complex syntactic structures (Adam \& Babiker, 2015).

Following the elaboration above, the researcher was interested in investigating the effectiveness of POWER (Plan, Organize, Write, Edit, and Revise) strategy to teach writing viewed from students' creativity. 


\section{Methods}

This research is experimental research conducted at one of the Senior High schools in Surakarta. Referring to this research, the researcher used a simple factorial design $2 \times 2$ with a post-test only design. This research involved three kinds of variables, namely independent variable, dependent variable, and attributive variable. The independent variable of this research was the teaching strategies. The strategies used were POWER and guided writing. The dependent variable of this research was the students' writing skills of senior high school.

Meanwhile, the attributive variable of this study was students' creativity in learning-this study conducted in August 2016 up to January 2017. The target population was the tenth-grade Senior High School students. The sampling used in this study was random cluster sampling. In this research, the researcher took two classes from seven classes of tenth-grade students as the sample. One class was an experimental group taught by POWER strategy, and the other was the control group taught using a guided writing strategy.

In this research, the researcher used two instruments in collecting the data. They were writing tests and creativity tests. Writing test was used to find out students' writing skill, while verbal creativity conducted to know students' creativity levels-both instruments assessed by using the readability of the test instruction. After the writing scores obtained, they sorted following students' creativity levels, high and low. The techniques used in analyzing the data of this study were descriptive and inferential analysis. The descriptive analysis used to determine the mean, median, mode, and standard deviation of the writing test. Before testing the hypothesis, normality and homogeneity test conducted. Then, it was followed by testing the research hypothesis using inferential analysis of variance $2 \times 2$.

\section{Discussion}

The data of this research distributed into eight groups:

1. The writing scores of the students taught by using POWER strategy (A1)

2. The writing scores of the students taught by using guided writing strategy (A2)

3. The writing scores of the students having a high level of creativity (B1)

4. The writing scores of the students having a low level of creativity (B2)

5. The writing scores of the students having a high level of creativity taught by using POWER strategy (A1B1)

6. The writing scores of the students having a low level of creativity taught by using POWER strategy (A1B2)

7. The writing scores of the students having a high level of creativity taught by using guided writing ( $\mathrm{A} 2 \mathrm{~B} 1$ )

8. The writing scores of the students with a low level of creativity taught using guided writing (A2B2) 
The data are analyzed by using Multifactor Analysis of Variance (ANOVA) $2 \times 2$. Before that, the normality and homogeneity of the data should test as the requirement to use ANOVA and Tukey test. The result of normality using the Lilliefors test shows that all data are average. As can see by comparing the values gained (Lo) and Stable, where the values (Lo) are lower than Lt. Thus, it can concluded that the data on both teaching strategies and creativity levels usually distributed. The computation of the normality test divided into eight groups of data summarized as follows:

Table 1. The Summary of Normality Test

\begin{tabular}{|c|c|c|c|c|c|c|}
\hline No & Variables & $\mathrm{L}_{\mathrm{o}}$ & $\mathbf{N}$ & $\overline{L_{t}}$ & $\begin{array}{l}\text { Test } \\
\text { Decision }\end{array}$ & Status \\
\hline 1 & $\begin{array}{l}\text { The writing scores of the students taught by } \\
\text { using POWER strategy }\left(A_{1}\right)\end{array}$ & 0.062 & 26 & 0.17 & $\begin{array}{l}\mathrm{H}_{\mathrm{o}} \text { is } \\
\text { accepted }\end{array}$ & Normal \\
\hline 2 & $\begin{array}{l}\text { The writing scores of the students taught by } \\
\text { using guided writing strategy }\left(A_{2}\right)\end{array}$ & 0.09 & 26 & 0.17 & $\begin{array}{l}\mathrm{H}_{\mathrm{o}} \text { is } \\
\text { accepted }\end{array}$ & Normal \\
\hline 3 & $\begin{array}{l}\text { The writing scores of the students having a } \\
\text { high level of creativity }\left(B_{1}\right)\end{array}$ & 0.061 & 26 & 0.17 & $\begin{array}{l}\mathrm{H}_{\mathrm{o}} \text { is } \\
\text { accepted }\end{array}$ & Normal \\
\hline 4 & $\begin{array}{l}\text { The writing scores of the students having a } \\
\text { low level of creativity }\left(B_{2}\right)\end{array}$ & 0.11 & 26 & 0.17 & $\begin{array}{l}\mathrm{H}_{\mathrm{o}} \text { is } \\
\text { accepted }\end{array}$ & Normal \\
\hline 5 & $\begin{array}{l}\text { The writing scores of the students having a } \\
\text { high level of creativity taught by using POWER } \\
\text { strategy }\left(A_{1} B_{1}\right)\end{array}$ & 0.11 & 13 & 0.234 & $\begin{array}{l}\mathrm{H}_{\mathrm{o}} \text { is } \\
\text { accepted }\end{array}$ & Normal \\
\hline 6 & $\begin{array}{l}\text { The writing scores of the students having a } \\
\text { low level of creativity taught by using POWER } \\
\text { strategy }\left(A_{1} B_{2}\right)\end{array}$ & 0.12 & 13 & 0.234 & $\begin{array}{l}\mathrm{H}_{\mathrm{O}} \text { is } \\
\text { accepted }\end{array}$ & Normal \\
\hline 7 & $\begin{array}{l}\text { The writing scores of the students having a } \\
\text { high level of creativity taught by using guided } \\
\text { writing }\left(A_{2} B_{1}\right)\end{array}$ & 0.11 & 13 & 0.234 & $\begin{array}{l}\mathrm{H}_{\mathrm{o}} \text { is } \\
\text { accepted }\end{array}$ & Normal \\
\hline 8 & $\begin{array}{l}\text { The writing scores of the students having a } \\
\text { low level of creativity taught by using guided } \\
\text { writing }\left(A_{2} B_{2}\right)\end{array}$ & 0.12 & 13 & 0.234 & $\begin{array}{l}\mathrm{H}_{\mathrm{o}} \text { is } \\
\text { accepted }\end{array}$ & Normal \\
\hline
\end{tabular}

Besides, the result of the homogeneity test shows that $\chi 02(0.10191)$ at the level of significance $a=0.05$ is lower than $\chi$ t2 (7.81), it can conclude that the data are homogeneous. It means the data obtained from the results for both variables are homogeneous. After finding normality and homogeneity of the data, the data analyzed by using Multifactor Analysis of Variance (ANOVA) $2 \times 2$. This test used to know the effect of the independent variable and attributive variable toward the dependent variable. Besides, ANOVA has the function to know if there is an interaction among the variables. The hypothesis rejected if Fo is higher than $\mathrm{Ft}(\mathrm{Fo}>\mathrm{Ft}$ ). The result of the data presented in the table below. 
Table 2. The Mean Scores

\begin{tabular}{|c|c|c|c|}
\hline Creativity (B) & Teaching Strategy (A) & Total & \\
\hline & POWER $\left(\mathrm{A}_{1}\right)$ & Guided Writing $\left(A_{2}\right)$ & \\
\hline \multirow[t]{2}{*}{ High Creativity $\left(B_{1}\right)$} & $\begin{array}{l}\Sigma=1064 \\
\bar{X}\end{array}$ & $\begin{array}{l}\Sigma=963 \\
\bar{X}\end{array}$ & $\begin{array}{l}\Sigma_{\mathrm{r} 1}=2027 \\
\bar{X}_{r_{1}}\end{array}$ \\
\hline & $=81.85$ & $=74.08$ & $=77.96$ \\
\hline \multirow[t]{2}{*}{ Low Creativity $\left(B_{2}\right)$} & $\begin{array}{l}\Sigma=904 \\
\bar{X}\end{array}$ & $\begin{array}{l}\Sigma=907 \\
\bar{X}\end{array}$ & $\begin{array}{l}\Sigma_{r_{2}}=1811 \\
\bar{X}_{r_{2}}\end{array}$ \\
\hline & $=69.54$ & $=69.77$ & $=69.65$ \\
\hline \multirow[t]{3}{*}{ Total } & $\begin{array}{l}\Sigma_{c_{1}}=1968 \\
\bar{X}_{c_{1}}\end{array}$ & $\begin{array}{l}\boldsymbol{\Sigma}_{\mathrm{c} 2}=1870 \\
\bar{X}_{c_{2}}\end{array}$ & $\sum_{X}{ }^{=3838}$ \\
\hline & $=75.69$ & $=71.92$ & 2 \\
\hline & & & $=73.81$ \\
\hline
\end{tabular}

Table 3. Summary of a $2 \times 2$ Multifactor Analysis of Variance

\begin{tabular}{llllll}
\hline $\begin{array}{l}\text { Source of } \\
\text { variance }\end{array}$ & SS & $\mathbf{d f}$ & $\mathbf{M S}$ & $\mathbf{F}_{\mathrm{o}}$ & $\mathbf{F}_{\mathbf{t}(0.05)}$ \\
\hline $\begin{array}{l}\text { Between } \\
\text { columns }\end{array}$ & 184.6923 & 1 & 184.6923 & 4.755633 & 4.04 \\
Between rows & 897.2308 & 1 & 897.2308 & 23.10275 & \\
Columns by rows & 208 & 1 & 208 & 5.355781 & \\
Between groups & 1289.923 & 3 & 429.9744 & & \\
Within group & 1864.154 & 48 & 38.83654 & & \\
\hline Total & $\mathbf{3 1 5 4 . 0 7 7}$ & $\mathbf{5 1}$ & & & \\
\hline
\end{tabular}

1. As seen from the result of the ANOVA test, the value of Ftable at the level of significance is $a=0.05$ is 4.04 , while the value of Fo is 4.75 , which means that Ho rejected and the difference between columns is significant. Besides, it can see at the mean score of both classes. The mean score of the students taught by POWER strategy is 75.69, and the mean score of the students taught by guided writing is 71.92. Thus, it can conclude that students who taught by using POWER strategy have better writing skills than those taught by guided writing.

2. The ANOVA test result shows that Fo between rows (23.10275) is higher than Ft at the level of significance $a=0.05$ (4.04). It means that Ho rejected, and the difference between rows is significant. In other words, the writing skills of the students who have high creativity and those who have low creativity are significantly different. Then, the mean score of B1 (77.96) is higher than B2 (69.65); it can conclude that high creativity students have better writing skills than those with low creativity.

3. The result of the ANOVA test shows that Fo columns by rows (5.35) are higher than $\mathrm{Ft}$ at the level of significance $\alpha=0.05$ (4.04). It means that Ho rejected, and there is an interaction between teaching strategies and students' creativity levels 
to teach writing. Thus, it can conclude that students' creativity levels influence the effectiveness of the teaching strategy.

If there are interaction and effect of independent variable toward the dependent variable based on ANOVA result, it is necessary to compare the mean of every treatment with the other means by using the Tukey test. This test used to identify which means are significantly different from one another. The following table shows a summary of the multiple comparison test using the Tukey Test.

Table 4. The Summary of the Tukey Test

\begin{tabular}{llll}
\hline Data & $\mathbf{q}_{\mathrm{o}}$ & $\mathbf{q}_{\mathrm{t}}$ & Description \\
\hline $\mathbf{A}_{1}-\mathbf{A}_{2}$ & 3.084034 & 2.907 & Significant \\
$\mathbf{B}_{1}-\mathbf{B}_{2}$ & 6.797462 & 2.907 & Significant \\
$\mathbf{A}_{1} \mathbf{B}_{1}-\mathbf{A}_{2} \mathbf{B}_{1}$ & 4.494997 & 3.055 & Significant \\
\hline $\mathbf{A}_{1} \mathbf{B}_{2}-\mathbf{A}_{2} \mathbf{B}_{2}$ & $\mathbf{0 . 1 3 4}$ & $\mathbf{3 . 0 5 5}$ & not significant \\
\hline
\end{tabular}

Based on the computation by using the Tukey Test in the summary above, it can be interpreted that:

1. Because qo between columns $A_{1}$ and $A_{2}$ (3.08) is higher than qt at the level of significance $\alpha=0.05$ (2.907), applying POWER strategy gives significantly different results from guided writing to teach writing. Besides, the mean of $A_{1}$ (75.69) is higher than that of $A 2$ (71.92); it shows that the POWER strategy is more effective than guided writing to teach writing.

2. Because qo between rows $B_{1}$ and $B_{2}(6.79)$ is higher than qt at the level of significance $\alpha=0.05$ (2.907), it can conclude that students have high creativity and those with low creativity are significantly different in their writing skill. The mean of B1 (77.96) is higher than B2 (69.65); it can say that students having high creativity have better writing than those having low creativity.

3. Because qo between cells $A_{1} B_{1}-A_{2} B_{1}$ (4.49) is higher than qt at the level of significance $a=0.05$ (3.055), applying POWER strategy gives a significantly different result from guided writing to teach writing to students having high creativity. Because the mean of $A_{1} B_{1}$ (81.85) is higher than that of $A_{2} B_{1}$ (74.08), it can say that the POWER strategy is more effective than guided writing to teach writing for students having high creativity.

4. Because qo between cells $A_{1} B_{2}-A_{2} B_{2}$ (0.134) is lower than qt at the level of significance $\alpha=0.05$ (3.055), the difference between columns for students having low creativity is not significant. It means that the POWER strategy is as effective as guided writing to teach writing for students having low creativity.

By considering the data analysis above, the following discusses the result of this research:

\section{A. The Differences between POWER and Guided Writing}

The research findings revealed that there is a significant difference between the POWER strategy and guided writing. The result shows that the POWER strategy is more 
effective than guided writing to teach writing. POWER is an organizational strategy to produce good writing by exploring and reinforcing students' ideas through the stages of the writing process. Moreover, teaching and learning writing becomes more effective by encouraging them to use an organized and systematic process. The students taught how to produce good writing covering what they should do to collect ideas, organize them into appropriate main ideas, and write a systematic text involving good aspects of writing, namely content, organization, grammar, vocabulary, and mechanics. As stated by Reid and Lienemann (2006), POWER is an organizational writing strategy that organizes all the steps in the writing process. Another reason why POWER is more effective than guided writing to teach writing focuses on its activity. POWER strategy is studentscentered rather than guided writing.

In the first stage, the students asked to brainstorm and collect their ideas about the topic chosen. Students organized their main ideas for each paragraph by making a tree diagram and arranging each of the information from the planning stage under each of the appropriate main ideas. The teacher asked the students to make a text that consists of some paragraphs systematically based on their tree diagram. After finishing their writing, students asked to check or edit their writing in line with organization, content, vocabulary, grammar, and mechanics with their partner. The students could suggest the correct writing. Then, the teacher gave feedback to the student. In the last stage, students asked to rewrite their correcting work in another paper and submit it to the teacher. Kamilasari (2013) argues that POWER strategy is a strategy which helps students organize and explore their ideas quickly as soon as it comes to their mind. Using the POWER strategy gives students the means to plan before they begin writing. This strategy guides students to be independent writers through several stages, namely plan, organize, write, edit, and revise that include in writing process stages. In other words, the teaching-learning process while applying the POWER strategy focuses more on student's activity, and the role of the teacher is to monitor student's activities and help them if needed.

Guided writing is less effective than POWER strategy to teach writing because guided writing is teacher-centered since teacher's role in applying this strategy is too dominant. Besides, the students have less chance to express their ideas since they are controlled and guided from the first to the last step. In teaching, guided writing provides many opportunities for the teacher to observe and teach writing to the students intensively, but it exactly hinders the students from creating their text and building their writing skills because they only follow the outline already provided by the teacher. They also often ask for the teacher's help in making a text as long as this strategy provides immediate assistance for the students. Usman \& Rizki (2016) state that guided writing is a strategy in teaching writing to the students in which the teacher provides feedback, redirection, and expansion of ideas. For example, the teacher creates an outline and gives guiding questions to evaluate students' writing. Specifically, guided writing used to assist the students during the writing process through the teacher's model and guidance. 
Therefore, in implementing this strategy, the students tend to be dependent and passive during teaching and learning activities.

In its implementation, the teacher gave the topic to the students and asked them to brainstorm everything they know about the topic and write their responses on the board. Then, the teacher reviewed students' ideas, decided which of them were major points and which were supporting details, and created an outline as a class outline. Students are given time to draft paragraphs using a class outline and collected them from the teacher. The teacher turned students' drafts along with the guiding questions used to evaluate their draft. After that, the teacher explained the common mistakes from the students' first draft and told what good things should be. The last teacher had students edit or revise their draft by using the guiding questions.

Guided writing, the students are always guided and controlled by the teacher from the first until the last stage. Besides, they are also not demanded to make corrections of their writing. Students only need to read and write about the topic given. Therefore, in the implementation of guided writing, the students' scientific and creative thinking cannot be facilitated properly. It also supported by Timayi (2015) that guided writing is a follow-up of the modeled and shared strategy in that the teacher gives scaffolding to the learners during the sessions and then encourages them to take on more of the writing process. It is proven that guided writing strategy lacks students' actual performance during the teaching and learning process. Teachers' guidance during the writing process may lead the students to be bored easily and tend to ignore any errors in their writing without any peer correction.

Based on the discussion above and the result of this research, it can be concluded that the POWER strategy is more effective than guided writing to teach writing for tenthgrade students of SMA Al-Abidin Bilingual Boarding School in the academic years of 2016/2017. It also supported by the mean score of the students taught by POWER strategy to teach writing, which is higher than that of those taught by using guided writing.

\section{B. The Differences between Students Having High Creativity and Students Having Low Creativity}

The research findings reveal that students having high creativity have better writing skills than those having low creativity. It is proven by the mean score of the students having high creativity, which is higher than that of those having low creativity. Students having high creativity can solve their learning problems, create something with their new ideas, and apply them better. Besides, creative students can adapt themselves to attain their goals. They can easily explore their ability because they think beyond what they see, read, and listen in doing something so they can produce good work. It is supported by Kaufman and Stenberg's statement (2006) that creative persons are characterized by their higher sensitivity and imagination, showing absolute self-sufficiency, openness to experience, independent thinking, and sense of humor. 
Following writing skills, students need not only an effective strategy to produce good writing but also their creativity. Creativity is an ability to think, act, and create something innovative that can be useful and valued in enriching the quality of life and learning. With high creativity, the students can produce better writing since they have more analytical thought to analyze, synthesize, generate, and determine their ideas. This statement is supported by Kaufman and Sternberg (2006) that creativity involves thinking aimed at producing ideas or products that are relatively novel and that are, in some respects and compelling.

On the contrary, students who have low creativity will just write what they see, read, and listen without thinking about what is beyond. They lack ideas and vocabulary to express them into the written text because they have a monotonous concept, idea, and creation in solving the problem. Besides, they do not want to take a risk and keep doing a simple task. As stated by Munandar (2014) that low creativity persons have less motivation, dependence, and inflexible thinking. These are the reasons why students having low creativity get lower writing scores than those having high creativity. Their low creativity becomes an obstacle for them to express their ideas better. It can see from the result of this research in which the writing scores of students having low creativity are lower than that of those having high creativity from both classes given treatment. Thus, students having high creativity are better in writing skills than those having low creativity.

\section{Interaction between Teaching Strategies and Students' Creativity on Students' Writing Skills}

POWER is an effective strategy to teach writing. This strategy encourages the students to produce good writing by exploring and reinforcing their ideas through the stages of the organized and systematic writing process. POWER strategy provides time for the students to expand and organize their ideas without any modeling. The students can stimulate their ideas and concentrate on producing their authentic writing through instruction. This strategy is beneficial in gaining students' writing skills. Kamilasari (2013) states that POWER strategy is a strategy which helps students organize and explore their ideas quickly as soon as it comes to their mind.

This strategy is also helpful for the students to remember the steps of the writing process by providing a letter to cue each step of the writing process, namely Plan, Organize, Write, Edit, and Revise. Nevertheless, to implement this strategy run well, the students must understand and follow every instruction before they began the POWER steps. The teacher gives help if needed during the process so that this strategy requires many students' attentions to do all the process well. POWER strategy gives students a chance to express their ideas freely since the process focuses on students' activity. Giving correction or feedback to their friends' writing is provided in the Edit stage of POWER strategy this has an aim to give a reflection on the teaching writing process through receiving comments, corrections, opinions, and additional information on their writing 
either by the teacher or other students. It can conclude that using POWER can foster the students to engage actively in the teaching-learning process and be an independent learner.

However, students will not produce creative and novel work if creative thinking is lacking. Under the goal of teaching writing using the POWER strategy, the implementation of this strategy requires high creativity students in order to obtain an optimum result. They have to think outside the box and apply their experience to create a novel and meaningful writing. Through the steps of writing in this strategy, the students also need more concentration and knowledge because this strategy encourages them to follow an organized and systematic process. As stated by Bakken and Whedon (2003) that POWER strategy is an effective tool to improve students' writing skills. This strategy manages students' ideas by following a sequential process. Besides, this strategy gives opportunities for students to correct other students' work and lead them to be active learners. Using POWER can help the students link their science ideas, discussion, and expository writing for building independent thinking and self-sufficiency for the students having high creativity.

Students having high creativity can solve their learning problems, create something with their new ideas, and apply them better. They tend to have high motivation, such as following teaching and learning activities well, doing teacher's instruction, and finishing the task well. Also, high creative students like challenges and enjoy every step of activities in exploring ideas. It is in line with Munandar (2014), who mentions that highly creative persons have imagination, interest, confidence, independent thinking, and high motivation; this also supported by the characteristics of creative persons mentioned by Kaufman and Stenberg (2006: 88) that creative persons are characterized by their greater sensitivity and imagination, showing certain self-sufficiency, openness to experience, independent thinking, and sense of humor. Therefore, students having high creativity can think beyond and use their creativity in exploring their ideas to finish their task.

Using the POWER strategy for students with high creativity will demand them to think creatively, so they can develop their ideas and create a more effective learning experience. Because this strategy is students-centered, POWER also allows students to exchange collective and individual feedback. As a result, they can produce good writing, especially an English text. Therefore, it requires students to have high creativity in such high creativity students can organize and explore their ideas creatively and write better. Thus, students with high creativity suitably taught using POWER strategy because the implementation of this strategy emphasizes student's critical and analytical thinking.

Different from high creativity, students having low creativity tend to be passive, less motivated, unserious, and dependent learners. During the learning process, they are different from those having high creativity. Students having low creativity are dependent. They need more help and support from the teacher during the teaching and learning process. It happens because they are lazy to do complex activities, need creative and analytical thinking. They like something simple and easy to do. According to Amabile 
(1997), low creative persons have lower intrinsic and extrinsic motivation. They avoid doing a difficult task or even know how to solve the problem they have. In line with a writing activity, students having low creativity will just write what they see, read, and listen without being able to think what is beyond. They lack ideas and vocabulary to express them into the written text because they have a monotonous concept, idea, and creation in solving the problem. Therefore, they find difficulties in writing, such as how to get the information, develop ideas, and arrange the sentences.

Because of the characteristics of students with low creativity, POWER strategy, and guided writing can be used to teach writing for students with low creativity. Students have poor writing skills because some characteristics of low creativity students demotivate them to improve and produce good writing. Fasco (2001, cited in Dieni, 2014) states that a learning strategy is not successfully applied when teaching low creative students. Therefore, POWER and guided writing can be used to teach writing to students having low creativity. According to Fazio and Gallagher (2009), POWER is memory mnemonic used as a strategy to reinforce the steps of the writing process. This strategy helps the students have low creativity to remember the steps of the writing process by providing a cue in each step to motivate them to follow the activities. Guided writing is also suitably applied for the students having low creativity. This strategy contributes to the teaching sequence and also students writing because they are supported and guided during the process. Guided writing is a strategy offering a series of simulators (Brown, 2001). The appropriate guidance of guided writing can be a stimulator to the students having low creativity to stimulate their ideas and encourage them to express their ideas into a written form. Thus, POWER strategy is as effective as guided writing to teach writing for students having low creativity because they reach the same improvement in their writing skills.

\section{Conclusion}

Based on the result of this study, the researcher draws some research findings:

1. POWER strategy is more effective than guided writing to teach writing;

2. Students having high creativity have better writing skill than those having low creativity, and

3. There is an interaction between teaching strategies and creativity to teach writing. Based on the research findings, it can conclude that the POWER strategy is useful to teach writing; this can see from the data analysis that the difference between columns for students having low creativity is not significant. Thus, POWER strategy is as effective as guided writing to teach writing for students having low creativity.

Besides, it suggested that: 
1. applying POWER strategy has a great impact on students' writing skills. Therefore, other English teachers suggested to use this strategy in their teaching and learning process;

2. it is better for the students to use POWER strategy so that they will be able to proceed good writing including content, organization, grammar, vocabulary, and mechanics aspect;

3. the result of this study can be useful as an additional reference in conducting similar research with different variables.

\section{References}

Adam, Ahmed Abdalla Saeed \& Babiker, Yousif Omer. (2015). The Role of Literature in Enhancing Creative Writing from Teachers' Perspectives. English Language and Literature Studies, Vol.5, No.1, ISSN 1925-4768 E-ISSN 1925-4776.

Amabile, Teresa M. (1997). Motivating Creativity in Organizations. California Management Review, Vol 40, No. 1.

Bakken,Jeffrey P \& Whedon,Craig K. (2003). Giving Students with Learning Disabilities the POWER to write: Improving the Quality and Quantity of Written Products. Learning Disabilities A Multidisciplinary Journal, Vol.12, No.1.

Barkaoui, Khaled. (2007). Teaching Writing to Second Language Learners: Insights from Theory and Research. TESL Reporter 40, 1 (2007), pp 35-48.

Brown, H. Douglas. (2001). Teaching by Principles: An Interactive Approach to Language Pedagogy. Second Edition. San Fransisco: San Fransisco State University.

Craft, Anna, et al. (2001). Creativity in Education. London: Continuum

Dieni, Novita. (2014). The Effectiveness of Visual Novel to Teach Writing Viewed from Students' Creativity (An Experimental Study at the Seventh Grade Students of SMP Al-Islam I Surakarta in the Academic Year of 2013/2014). Unpublished thesis. Surakarta: UNS.

Fazio, Xavier \& Gallagher, Tiffany. (2009). Supporting Students' Writing in Elementary Science: Tools to Facilitate Revision of Inquiry-Based Composition. Electronicournal of Literacy Through Science. Retrieved from http://ejlts.usdavis.edu

Huy, Nguyen Thanh. (2015). Problem Affecting Learning Writing Skill of Grade 11 at Thong Linh High School. Asian Journal of Educational Research. Vol.3, No. 2 ISSN 2311-6080.

Kamilasari, Nur. (2013). Teaching writing by Combining RAFT (Role, Audience, Format, Topic) and POWER (Plan, Organize, Write, Edit, Revise) Strategy at Senior High School. Jurnal Pendidikan Bahasa Inggris, Vol.2, No.2 (2013).

Kaufman, James C, \& Strenberg, Robert J. (2006). The International Handbook of Creativity. Cambridge: Cambridge University Press.

Kellogg, Ronald T. (2008). Training Writing Skills: A Cognitive Developmental Perspective. Journal of Writing Research, 1(1), 1-26.

Munandar. (2014). Pengembangan Kreativitas Anak Berbakat. Jakarta: PT. Rineka Cipta.

Reid, Robert \& Lienemann, Torri Ortiz. (2006). Strategy Instruction for Students with Learning Disabilities. New York: The Guilford Press.

Usman, Bustami \& Rizki Zahratur. (2016). Using The Guided Writing Technique To Teach Writing of Analytical Exposition Texts. English Education Jurnal (EEJ), 7(1), 29-45.

Cite: Nur Istianah, T. (2020). Power (Plan, Organize, Write, Edit, and Revise) Strategy: Teaching Writing Viewed from Students' Creativity. Diadikasia Journal, 1(1), 103-114. https://doi.org/10.21428/8c841009.a6eedoc3 